\title{
Yield and quality of groundnut genotypes as affected by different sources of sulphur under rainfed conditions
}

\author{
Abdul Manaf ${ }^{1^{*}}$, Muhammad Navid Akhtar ${ }^{1}$, Muhammad Tariq Siddique ${ }^{2}$, Muhammad Iqbal $^{3}$ and \\ Humair Ahmed ${ }^{4}$ \\ ${ }^{I}$ Department of Agronomy, PMAS- Arid Agriculture University Rawalpindi, Pakistan \\ ${ }^{2}$ Department of Soil Science \& SWC, PMAS-Arid Agriculture University Rawalpindi, Pakistan \\ ${ }^{3}$ Space Applications and Research Complex, Pakistan Space and Upper Atmosphere Research Commission, Islamabad \\ ${ }^{4}$ Land Resources Research Institute, NARC, Islamabad
}

\begin{abstract}
A field experiment was conducted to determine the response of groundnut genotypes to sulphur sources at Koont Research Farm of PMAS-Arid Agriculture University Rawalpindi under rainfed conditions during April 2013. Experiment was comprised of four groundnut genotypes viz. Bari-2011, Golden, Bard-92 and PG-1058 and three sources of sulphur (S) SSP (45 $\left.\mathrm{kg} \mathrm{ha}^{-1}\right)$, SOP $\left(45 \mathrm{~kg} \mathrm{ha}^{-1}\right)$ and gypsum $\left(400 \mathrm{~kg} \mathrm{ha}^{-1}\right)$ with control. Results revealed that genotype Bari-2011 gave best performance for number of plants $\mathrm{m}^{-2}$, number of pegs plant ${ }^{-1}$, number of pods plant $^{-1}$, number of seeds pod ${ }^{-1}$, seed index, seed yield and harvest index. Sources of sulphur depicted statistically significant results for yield and quality parameters of groundnut genotypes. Among sources of sulphur SSP revealed best performance for all studied with an increase of $81.5 \%$ in grain yield compared to control. Among interactive effect of genotypes and sulphur fertilizers, genotype Bari-2011 along with SSP gave maximum results for all parameters studied.
\end{abstract}

Keywords: Groundnuts, genotypes, sulphur sources, yield

\section{Introduction}

Groundnut (Arachis hypogaea L.) is a conventional oil seed crop grown in rainfed areas of Punjab, Pakistan (Nazir et al., 2011). It's seeds contain 43-55\% oil contents (Din et al., 2009), 24-26\% protein, $45-48 \%$ fat, $3 \%$ fiber and 15 $18 \%$ carbohydrates (Shokunbi et al., 2012). It is a dietary source of calcium, magnesium, iron, zinc, phosphorus, vitamin $\mathrm{E}$, riboflavin, thiamine and potash. This crop is also used in the form of fodder, seeds, straw and hay (Smith, 2002). Groundnut serves as an important source of food and energy. It can be used as food (cooking oil, raw, roasted) feed (green material, straw, seed pressings) and used in industry as a raw material (Onyeike and Oguike, 2003). Use of groundnut reduces the risk of cardiovascular disease (Etherton et al., 1999), breast cancer, colon and prostate (Awad et al., 2000). It may also reduce osteoporosis (Messina, 1999), diabetes (Jiang et al., 2000). Groundnut is associated with many metabolic benefits in reducing obesity and metabolic syndrome (Coates and Howe, 2007), it also increases the soil fertility due to its leguminous nature by fixing atmospheric nitrogen (Hossain et al., 2006).

Sulphur (S) is a secondary nutrient for plant growth and development (Jamal et al., 2010). It is least plentiful essential macronutrient in plants. For the formation of organic metabolites nitrogen and sulphur are needed which are absorbed from soil in the form of sulphates $\left(\mathrm{SO}_{4}{ }^{-2}\right)$ through roots. It plays very important role in catalytic and electrochemical functions of biomolecules in the cells (Saito, 2004). Positive response of sulphur application has been observed in groundnut (Mishra et al., 1999). It improves dry matter, plant height, number and weight of seed, seed yield and biological yield (Poonia, 2000). The application of elemental sulphur resulted significantly high yield, micro-nutrient content and uptake in groundnut (Sisodiya et al., 2017). Significantly high increase in number of pods and seeds /plant, weight of pods and seeds /plant, 100-seed weight as well as seed oil and protein yields was observed in another study dealing with sulphur application and foliar spraying with Zinc and Boron on yield, yield components, and seed quality of Peanut (ELKader and Mona, 2013).

Several studies resulted that application of different sulphur containing fertilizers exposed differential impact on the growth, development and production of crops. Single super phosphate (SSP) is an important source of sulphur. It has substantial effect on grain yield, total biological yield, sulphur concentration in grain, total sulphur uptake, grain protein content, oil content and oil yield (Chattopaddhyay, 2012). Sulphate of potash (SOP) is another key source of

*Email: munafawan@yahoo.com 
sulphur. It increases the pod yield, kernal yield, individual grain weight and oil content (Ramdevputra et al., 2010, Dwivedi and Bapat, 1998). Gypsum $\left(\mathrm{CaSO}_{4} \cdot 2 \mathrm{H}_{2} \mathrm{O}\right)$ is a general name for a mineral compound called calcium sulphate. Gypsum has equal or better effect on groundnut as other S containing fertilizers. Formation of vitamin and chlorophyll is affected by the application of gypsum (Ghosh et al., 2000). The yield and quality of oilseed crops are decreasing due to deficiency of sulphur as it is essential with nitrogen for protein and enzymes synthesis. Moreover sulphur also forms part of cysteine, methionine, amino acids and many secondary compounds in plants. The quality of crop may also be influenced by the amount and kind of these compounds, it may increase the nutritional value for human and animals (Ahmad and Abdin, 2000).

The current study was conducted to evaluate the effect of different sources of sulphur on growth, yield, quantity and quality of oil contents in different groundnut genotypes under rainfed conditions.

\section{Materials and Methods}

\section{Experimental site}

To evaluate the yield and yield attributing characters of groundnut genotypes as influenced by different sources of sulphur, a field experiment was conducted at Koont Research Farm, PMAS-Arid Agriculture University, Chakwal during Kharif season 2013, located at latitude of $33.06^{\circ} \mathrm{N}$, longitude $73.00^{\circ} \mathrm{E}$, and 502 meters above sea level with annual rainfall of $650-850 \mathrm{~mm}$. The precipitation conditions prevailed during crop growth period is shown in Fig. 1 and the soil physiochemical characteristics of experimental site are shown in table. 1 .

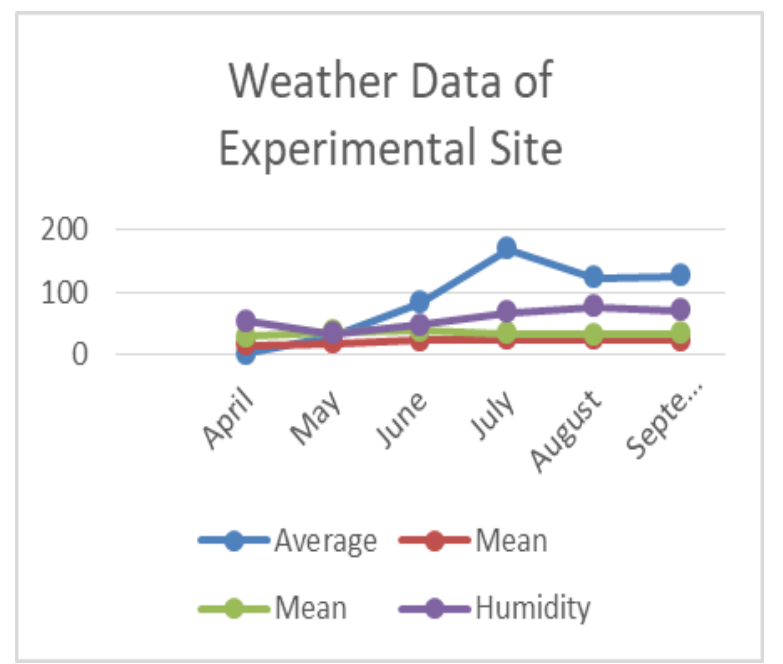

Figure 1: Precipitation data of the experimental site from April 2013 to September 2013

\section{Soil analysis}

Soil texture was determined by dispersion in sodium hexametaphosphate $\left(\mathrm{Na}\left(\mathrm{PO}_{3}\right)_{6}\right)$ and density of suspension was recorded by hydrometer at specific time intervals (Gee and Bauder, 1982). Soil $\mathrm{pH}$ was determined using 1:2.5 suspension of soil in deionized water (Thomas and Hipp, 1996). Electrical conductivity was determined using 1:2.5 suspension of soil in deionized water. Then the EC of the supernatant liquid was measured at $25{ }^{\circ} \mathrm{C}$ using conductivity meter after standardization with $0.01 \mathrm{~N} \mathrm{KCl}$ (Rhoades, 1996). Organic matter was determined through wet digestion method by using $1 \mathrm{~N}$ potassium dichromate solution and concentrated sulphuric acid and was titrated against $0.5 \mathrm{~N}$ ferrous ammonium sulphates (Nelson and Sommers., 1982). Cation exchange capacity was determined by using $1 \mathrm{M}$ sodium acetate at $\mathrm{pH} 8.5$ (Rhoades and Polemio., 1977). $\mathrm{CaCO}_{3}$ content in the soil was determined using $\mathrm{HCl}$ and titration against $1 \mathrm{~N} \mathrm{NaOH}$ to a faint pink color end point (Soltanpour and Workman, 1981).

\section{Treatments and cultivation practices}

Field research was laid out in randomized complete block design (split plot) with four replicates. Four groundnut genotypes viz. Bari-2011, Golden, Bard-92 and PG-1058 were tested. Nitrogen, $\mathrm{P}$ and $\mathrm{K}$ nutrient rates were maintained at the rate of 25,80 and $25 \mathrm{~kg}$ per ha $(\mathrm{S} 1=0)$. Whereas sulphur was applied @ $45 \mathrm{~kg} / \mathrm{ha}$ in the form of SSP, SOP and gypsum (S2, S3 and S4 respectively). Genotypes and sulphur fertilizers were kept in main and sub plots respectively. There were six rows in each subplot by keeping row to row distance $45 \mathrm{~cm}$ and plant to plant distance $15 \mathrm{~cm}$ after thinning. While, the size of main plot was $32.4 \mathrm{~m}^{2}$ and subplot was $8.1 \mathrm{~m}^{2}$. Seed rate was used @ $100 \mathrm{~kg} \mathrm{ha}^{-1}$.

\section{Plant parameters recorded}

At maturity data of crop yield and yield contributing characters viz. number of plants per unit area, number of pegs per plant, number of pods per plant, number of seeds per pod, 100 seed weight, biological yield, seed yield and harvest index were recorded. Seed quality parameters viz. oil content, protein content, fatty acid profile. Seed oil content was measured by NMR system, protein content was determined by Kjeldahl method and fatty acids were determined by Gas Chromatography.

\section{Statistical analysis}

Computer Statistical Program STATISTIX 8.1 was used to analyze the data. ANOVA technique was used to check the overall significance of data and least significant 
difference (LSD) test at 5\% probability level was employed to compare the treatment's mean (Montgomery, 2001).

\section{Results and Discussion}

\section{Impact of sulphur sources on yield and attributing characteristics}

Genotypes Bari-2011 and PG-1058 produced maximum number of plants per meter square than in Golden which was statistically at par with Bard-92 (Table. 2). The significant variances among different genotypes are in line with findings of Subhendu et al., (2005) who reported that gypsum application @ $400 \mathrm{~kg}$ per hectare significantly increased number of plants $\mathrm{m}^{-2}$. Das and Garnayak (1995) noticed maximum plant density when gypsum was applied @ $60 \mathrm{~kg} \mathrm{ha}^{-1}$.

Groundnut genotypes and different sources of sulphur showed statistically significant differences for number of pegs per plant (Table. 2). Maximum number of pegs per plant was recorded in Bari-2011 while the genotype PG1058 produced minimum. These variations amongst the

Table 1: Physical and Chemical Properties of the Experimental Site.

\begin{tabular}{|c|c|c|c|c|}
\hline \multirow[b]{2}{*}{ DEPTH } & \multicolumn{2}{|c|}{ Before Sowing } & \multicolumn{2}{|c|}{ After Harvest } \\
\hline & $00-15 \mathrm{~cm}$ & $15-30 \mathrm{~cm}$ & $00-15 \mathrm{~cm}$ & $15-30 \mathrm{~cm}$ \\
\hline Texture & sandy clay loam & sandy clay loam & sandy clay loam & sandy clay loam \\
\hline Saturation (\%) & 38 & 38 & 37 & 37 \\
\hline Soil pH & 7.4 & 7.5 & 7.41 & 7.5 \\
\hline$E C\left(d_{s m}^{-1}\right)$ & 0.82 & 0.83 & 0.85 & 0.90 \\
\hline Organic Matter (\%) & 0.88 & 0.57 & 0.85 & 0.55 \\
\hline Available $P\left(\mathrm{mg} \mathrm{kg}^{-1}\right)$ & 8.2 & 5.2 & 7.8 & 5.0 \\
\hline Available $\mathrm{K}\left(\mathrm{mg} \mathrm{kg}^{-1}\right)$ & 120 & 80 & 110 & 90 \\
\hline SO4-S (ppm) & 16.24 & 17.51 & 19.44 & 18.62 \\
\hline
\end{tabular}

Table 2: Effect of genotype and sulphur application on yield and yield components of groundnut during 2013.

\begin{tabular}{|c|c|c|c|c|c|c|c|c|}
\hline Treatments & $\begin{array}{l}\text { No of Plant } \\
\mathrm{m}^{-2}\end{array}$ & $\begin{array}{c}\text { No.of } \\
\text { pegsplant }^{-1}\end{array}$ & $\begin{array}{c}\text { No.of } \\
\text { podsplant }^{-1}\end{array}$ & $\begin{array}{l}\text { No.of seed } \\
\text { pod }^{-1}\end{array}$ & $\begin{array}{c}100 \text { seed } \\
\text { weight }\end{array}$ & $\begin{array}{l}\text { Biological } \\
\text { yield }\end{array}$ & $\begin{array}{l}\text { Seed } \\
\text { yield }\end{array}$ & $\begin{array}{l}\text { Harvest } \\
\text { index }\end{array}$ \\
\hline \multicolumn{9}{|c|}{ Genotypes $(\mathbf{G})$} \\
\hline Bari-2011 & 7.09 & 96.62 & 85.16 & 1.92 & 74.76 & 8123.6 & 1178.6 & 12.99 \\
\hline Golden & 6.28 & 91.17 & 76.62 & 1.68 & 74.44 & 7900.6 & 975.1 & 12.22 \\
\hline Bard-92 & 6.34 & 91.57 & 78.49 & 1.67 & 60.55 & 8181.6 & 864.0 & 10.62 \\
\hline Pg-1058 & 7.09 & 88.78 & 75.77 & 1.76 & 60.37 & 8186.5 & 880.6 & 10.73 \\
\hline $\mathrm{LSD} \leq \mathbf{0 . 0 5}$ & 0.5 & 6.5 & 4.5 & 0.02 & 0.9 & 422.9 & 68.1 & 1.1 \\
\hline \multicolumn{9}{|c|}{ Sulphur sources $\left(\mathrm{kg} \mathrm{ha}^{-1}\right)$} \\
\hline Control & 5.75 & 76.35 & 59.46 & 1.62 & 64.70 & 6578.9 & 652.0 & 10.08 \\
\hline $\mathrm{SSP}$ (45 kg ha- 1 ) & 6.78 & 105.36 & 93.51 & 1.90 & 69.43 & 8635.6 & 1183.8 & 12.38 \\
\hline SOP (45 kg ha-1) & 7.00 & 96.02 & 85.30 & 1.73 & 67.90 & 8464.7 & 1049.3 & 12.41 \\
\hline $\begin{array}{c}\text { Gypsum (400 kg } \\
\left.\mathrm{ha}^{-1}\right)\end{array}$ & 7.28 & 90.44 & 77.70 & 1.77 & 68.09 & 8713.1 & 1013.1 & 11.68 \\
\hline LSD $\leq \mathbf{0 . 0 5}$ & 0.6 & 7.2 & 6.54 & 0.03 & 1.0 & 381.3 & 51.8 & 0.9 \\
\hline
\end{tabular}

were credited to the different response of the genotypes to the environmental circumstances like variation in temperature and rainfall prevailing during the crop period. Gypsum fertilizer produced the maximum number of plants $\mathrm{m}^{-2}$ followed by SSP and SOP whereas minimum numbers of plants were observed in control treatment. Genotypes and sources of sulphur interactive effect depicted that (Table. 3) Bari-2011 along with Gypsum application produced maximum number of plants per $\mathrm{m}^{2}$ compared to Bari-2011 with control. Other interactive effects showed varied degree of differences. These results different genotypes might be due to particular genetic makeup of genotypes and their place of origin as well as environmental conditions. Among different sources of sulphur, SSP produced maximum number of pegs per plant. Whereas, the minimum number of pegs per plant were detected in control treatment (Table. 3). The genotype Bari2011 produced maximum number of pegs where SSP was applied. While minimum pegs were recorded in same genotype (Bari-2011) with control treatment. These results are in line with the findings of Dutta et al. (2000) who 
reported significant increase in number of pegs per plant with the application of sulphur @ $60 \mathrm{~kg} \mathrm{ha}^{-1}$.

Genotypes and sources of sulphur revealed statistically significant differences for number of pods per plant (Table. 2). Maximum number of pods per plant was recorded in Bari-2011 while minimum was produced by PG-1058. Among sulphur sources maximum number of pods per plant was recorded in SSP while minimum was produced in control. Interactive effect of genotype and sulphur fertilizer showed significant variations (Table. 3). Bari-2011 using SSP produced maximum number of pods per plant whereas, minimum was observed in Bari-2011 with control. These results are in accordance with Kalaiyarasan et al., (2002) who reported that application of sulphur @ $45 \mathrm{~kg}$ per hectare significantly increased the number of pods per plant of groundnut, while Jamal et al. (2006) reported significant produced maximum number of seeds per pod whereas minimum number of seeds per pod were observed in control. Interactive effect of Bari-2011 and SSP fertilizer produced maximum number of seeds per pod while minimum was recorded in Golden with control treatment. These results are in accordance with findings of Jamal et al. (2006). They found significant increase in number of seed pod $^{-1}$ with application of sulphur @ $20 \mathrm{~kg} \mathrm{ha}^{-1}$. Similarly, Singh (2007) who used different levels of sulphur 0, 45 and $80 \mathrm{~kg}$ per hectare and reported S @ $45 \mathrm{~kg}$ per hectare produced higher number of seeds per pod. Kumaran (2001) also reported that sulphur @ $400 \mathrm{~kg}$ per hectare produced maximum number of seeds per pod.

Seed weight directly and positively influence the yield of crop. Groundnut genotypes, sulphur fertilizers and their interaction (Table. $2 \& 3$ ) exhibited statistically significant

Table 3: Interactive effect of groundnut genotypes and sulphur fertilizers on growth and yield characters.

\begin{tabular}{|c|c|c|c|c|c|c|c|c|c|}
\hline \multicolumn{2}{|c|}{ Treatments } & \multirow[b]{2}{*}{$\begin{array}{l}\text { No. of } \\
\text { plant } \\
\mathbf{m}^{-2}\end{array}$} & \multirow[b]{2}{*}{$\begin{array}{l}\text { No of } \\
\text { pegs } \\
\text { plant }^{-1}\end{array}$} & \multirow[b]{2}{*}{$\begin{array}{c}\text { No. of } \\
\text { pods } \\
\text { plant }^{-1}\end{array}$} & \multirow[b]{2}{*}{$\begin{array}{l}\text { No. of } \\
\text { seeds } \\
\text { pod }^{-1}\end{array}$} & \multirow[b]{2}{*}{$\begin{array}{c}100 \text {-seed } \\
\text { weight } \\
\text { (g) }\end{array}$} & \multirow[b]{2}{*}{$\begin{array}{c}\text { Biological } \\
\text { weight } \\
\left(\mathrm{kg} \mathrm{ha}^{-1}\right)\end{array}$} & \multirow[b]{2}{*}{$\begin{array}{c}\text { Seed yield } \\
\left(\mathrm{kg} \mathrm{ha}^{-1}\right)\end{array}$} & \multirow[b]{2}{*}{$\begin{array}{c}\text { Harves } \\
\text { index } \\
(\%)\end{array}$} \\
\hline Genotype & $\begin{array}{c}\text { Sources of } \\
\text { Sulphur }\end{array}$ & & & & & & & & \\
\hline \multirow{4}{*}{ Bard-2011 } & Control & 5.0 & 65.3 & 53.1 & 1.6 & 72.9 & 6409 & 715.5 & 12.6 \\
\hline & SSP & 7.4 & 127.5 & 116.5 & 2.4 & 78.4 & 9188 & 1484.8 & 11.0 \\
\hline & SOP & 6.8 & 97.5 & 86.4 & 1.9 & 74.0 & 8829 & 1279.5 & 14.6 \\
\hline & Gypsum & 9.3 & 96.3 & 84.7 & 1.8 & 73.8 & 9003 & 1234.5 & 13.8 \\
\hline \multirow{5}{*}{ Golden } & Control & 6.0 & 81.8 & 61.2 & 1.6 & 67.9 & 7071 & 600.3 & 9.4 \\
\hline & SSP & 5.9 & 102.0 & 89.6 & 1.7 & 77.8 & 8428 & 1270.3 & 15.1 \\
\hline & SOP & 6.9 & 92.9 & 83.9 & 1.6 & 75.4 & 8424 & 1107.8 & 13.3 \\
\hline & Gypsum & 6.4 & 87.9 & 71.8 & 1.8 & 76.7 & 8341 & 922.3 & 11.1 \\
\hline & Control & 6.3 & 84.5 & 64.4 & 1.7 & 59.3 & 7129 & 624.3 & 8.9 \\
\hline \multirow{3}{*}{ Bard } & SSP & 6.5 & 95.6 & 82.6 & 1.7 & 60.9 & 8401 & 917.3 & 10.9 \\
\hline & SOP & 7.1 & 97.0 & 87.9 & 1.6 & 61.3 & 8419 & 891.8 & 10.6 \\
\hline & Gypsum & 5.5 & 89.2 & 78.9 & 1.7 & 61.0 & 8604 & 1022.8 & 12.1 \\
\hline \multirow{5}{*}{ PG-1058 } & Control & 5.6 & 73.5 & 59.1 & 1.7 & 58.8 & 7129 & 668 & 9.4 \\
\hline & SSP & 7.3 & 96.3 & 85.3 & 1.8 & 60.9 & 8525 & 1063 & 12.5 \\
\hline & SOP & 7.2 & 96.7 & 83.1 & 1.8 & 60.9 & 8188 & 918.3 & 11.2 \\
\hline & Gypsum & 8.0 & 88.3 & 75.5 & 1.8 & 60.9 & 8905 & 873 & 9.8 \\
\hline & LSD (5\%) & 1.30 & 14.43 & 13.08 & 0.06 & 2.00 & 762.6 & 103.1 & 1.90 \\
\hline
\end{tabular}

increase in number of pods per plant with application of sulphur@20 kg ha-1.

Statistically significant variations were found among the groundnut genotypes, sources of sulphur and their interaction for number of seeds per pod. Among genotypes maximum number of seeds per pod were recorded in Bari2011 while Bard-92 attained minimum number of seeds which was statistically at par with Golden. Genetic response and prevailing environmental status might be the reason for variations found among genotypes for number of seeds per pod. In view the various sources of sulphur, SSP differences for hundred seed weight (seed index). Lowest seed index was documented in Bari-2011 while highest 100 seed weight was recorded in PG-1058 which was statistically same with Bard-92. Genetic formations of genotypes of different origin and environmental factors during crop period might be responsible for variation of genotypes for this trait. Among different sulphur fertilizers maximum 100-seed weight was recorded by SSP whereas, control treatment gained minimum seed index. In cultivar into sulphur interaction, Bari-2011 beside the application of SSP fertilizer attained highest seed index whereas, lowest 100-seed weight was recorded in PG-1058 with control. 
These results are in line with the findings of Jamal et al. (2006) who reported significant increase in 100-seed weight with application of sulphur @ $20 \mathrm{~kg}$ per hectare.

Genotypes showed statistically non-significant differences for biological yield but the sulphur fertilizers and their interaction with genotypes were statistically significant (Table. 2 and 3). Among sulphur sources, highest biomass production was produced by gypsum which was statistically similar with SSP and SOP, whereas, maximum biological yield and the same genotype produced minimum biological yield in control treatment. It is inferred that Bari-2011 is greatly influenced by sulphur fertilizer (SSP). Prasad, (2003) also reported significant increase in biological yield when sulphurwas applied @ $40 \mathrm{~kg} \mathrm{ha}^{-1}$.

Genotypes and sulphur fertilizers revealed statistically significant impact for seed yield. Maximum seed yield was produced by Bari-2011 while minimum was recorded in Bard-92 followed by PG-1058. Genetic diversity of

Table 4: Effect of genotype and sulphur application on oil content and quality of groundnut.

\begin{tabular}{|c|c|c|c|c|c|c|}
\hline Treatments & Oil Content & $\begin{array}{l}\text { Protein } \\
\text { Content }\end{array}$ & Palmitic acid & Stearic acid & $\begin{array}{c}\text { Linolenic } \\
\text { acid }\end{array}$ & Oleic acid \\
\hline \multicolumn{7}{|c|}{ Genotypes (G) } \\
\hline Bari-2011 & 52.9 & 27.8 & 8.7 & 4.2 & 31.4 & 45.8 \\
\hline Golden & 52.5 & 27.6 & 8.6 & 4.2 & 31.5 & 42.5 \\
\hline Bard-92 & 51.8 & 27.5 & 8.3 & 4.0 & 30.4 & 43.1 \\
\hline PG-1058 & 50.9 & 27.2 & 8.5 & 3.8 & 31.2 & 47.2 \\
\hline $\mathbf{L S D} \leq \mathbf{0 . 0 5}$ & 1.3 & 0.8 & 0.3 & 0.3 & 0.04 & 2.7 \\
\hline \multicolumn{7}{|c|}{ Sulphur sources $\left(\mathrm{kg} \mathrm{ha}^{-1}\right)$} \\
\hline Control & 52.3 & 26.2 & 7.3 & 3.5 & 27.8 & 39.4 \\
\hline $\operatorname{SSP}\left(45 \mathrm{~kg} \mathrm{ha}^{-1}\right)$ & 52.6 & 28.5 & 9.0 & 4.3 & 32.4 & 45.1 \\
\hline SOP $\left(45 \mathrm{~kg} \mathrm{ha}^{-1}\right)$ & 53.1 & 27.6 & 8.9 & 4.2 & 32.3 & 47.5 \\
\hline Gypsum $\left(400 \mathrm{~kg} \mathrm{ha}^{-1}\right)$ & 50.1 & 27.7 & 8.8 & 4.2 & 32.0 & 46.6 \\
\hline $\mathbf{L S D} \leq \mathbf{0 . 0 5}$ & 1.3 & 0.7 & 0.5 & 0.3 & 0.3 & 2.1 \\
\hline
\end{tabular}

Table 5: Interactive effect of groundnut genotypes and sulphur fertilizers on oil content and quality of groundnut

\begin{tabular}{|c|c|c|c|c|c|c|c|}
\hline \multicolumn{2}{|c|}{ Treatments } & \multirow{2}{*}{$\begin{array}{c}\text { Oil } \\
\text { Content }\end{array}$} & \multirow{2}{*}{$\begin{array}{l}\text { Protein } \\
\text { Content }\end{array}$} & \multirow{2}{*}{$\begin{array}{l}\text { Palmitic } \\
\text { acid }\end{array}$} & \multirow{2}{*}{$\begin{array}{c}\text { Stearic } \\
\text { acid }\end{array}$} & \multirow{2}{*}{$\begin{array}{l}\text { Linolenic } \\
\text { acid }\end{array}$} & \multirow[t]{2}{*}{ Oleic acid } \\
\hline Genotype & $\begin{array}{c}\text { Sources of } \\
\text { Sulphur }\end{array}$ & & & & & & \\
\hline \multirow{4}{*}{ Bard-2011 } & Control & 53.2 & 26.1 & 7.8 & 3.8 & 28.4 & 42.4 \\
\hline & SSP & 52.8 & 28.4 & 9.0 & 4.5 & 32.1 & 44.1 \\
\hline & SOP & 54.3 & 28.1 & 8.7 & 4.3 & 33.7 & 49.3 \\
\hline & Gypsum & 52.2 & 28.6 & 9.2 & 4.3 & 31.4 & 47.5 \\
\hline \multirow{5}{*}{ Golden } & Control & 51.6 & 26.8 & 7.1 & 3.4 & 27.8 & 37.6 \\
\hline & SSP & 53.2 & 28.2 & 9.2 & 4.6 & 33.3 & 42.5 \\
\hline & SOP & 52.6 & 27.9 & 9.2 & 4.4 & 31.5 & 47.6 \\
\hline & Gypsum & 49.8 & 27.4 & 8.8 & 4.4 & 33.3 & 42.2 \\
\hline & Control & 50.9 & 26.1 & 7.1 & 3.4 & 27.8 & 37.4 \\
\hline \multirow{3}{*}{ Bard } & SSP & 51.2 & 28.5 & 8.7 & 4.4 & 31.7 & 43.6 \\
\hline & SOP & 52.7 & 27.9 & 8.8 & 4.1 & 31.5 & 43.2 \\
\hline & Gypsum & 48.9 & 27.4 & 8.7 & 4.3 & 30.7 & 48.4 \\
\hline \multirow{5}{*}{ PG-1058 } & Control & 53.5 & 26.0 & 7.3 & 3.4 & 27.4 & 40.3 \\
\hline & SSP & 53.1 & 28.7 & 9.3 & 3.8 & 32.5 & 50.2 \\
\hline & SOP & 52.9 & 29.4 & 8.9 & 3.9 & 32.4 & 49.9 \\
\hline & Gypsum & 50.6 & 27.7 & 8.5 & 4.1 & 32.7 & 48.5 \\
\hline & LSD (5\%) & 2.6 & 1.5 & 0.9 & 0.5 & 0.5 & 4.3 \\
\hline
\end{tabular}

control produced the lowest biological yield. Interaction revealed that Bari-2011 along with SSP produced genotypes, their origins and environmental conditions directly influence the growth characters which directly 
influence the final yield. Among sources of sulphur, SSP produced maximum seed yield, however, minimum yield was recorded in control. Bari-2011 x SSP produced maximum seed yield while minimum seed yield was observed in Golden by control treatment. These results are in accordance with Nabi et al., (1999) who reported that SSP applied @ $45 \mathrm{~kg}$ per hectare produced highest seed yield. Similarly, Jamal et al. (2006) reported significant increase in seed yield with application of sulphur@ $20 \mathrm{~kg}$ $\mathrm{ha}^{-1}$.

Statistically significant differences were found among the genotypes, sources of sulphur and their interaction (Table. 2 and 3). Bari-2011 produced highest harvest H.I. index while lowest harvest index value was recorded in Bard-92. Maximum harvest index was obtained by SOP fertilizer which was statistically at par with SSP and gypsum while minimum H.I. was recorded in control. Genotype Golden with SSP produced maximum harvest index while minimum H.I. was observed in Bard-92 with control treatment. Jamal et al., (2010) concluded that H.I was significantly enhanced when sulphur was applied @ 20 $\mathrm{kg}$ per hectare.

According to Tabatabaei (1986), the sulfur increases seed yield and plant nutrition because it improves the soil reaction that causes an increase in the absorbable phosphorous of the soil. Similar work has also been reported by Sarkar et al. (2002). Ishag (1992) and Abd ElHady (2007) mentioned that foliar application of micronutrients increases the concentrations of macro and micronutrients in peanuts seeds and this occurs because of the vital physiological roles in plant cells that improve the uptake of plant nutrients.

\section{Impact of sulphur sources on seed quality}

Among genotypes (Table 4) Bari-2011 accumulated maximum oil content followed by PG-1058 and Golden. Whereas, minimum oil content was recorded in Bard-92 which was statistically at par with Golden. Sources of sulphur showed statistically non-significant differences for oil content while interactive effect of genotypes $\mathrm{x}$ sources of sulphur showed statistically significant differences for oil content accumulation (Table 5). Maximum oil content were accumulated in Bari-2011 x SOP whereas, minimum were observed in the Bard-92 $\mathrm{x}$ gypsum.

Genotypes (Table 4) showed statistically nonsignificant differences for protein content while among sulphur sources maximum protein content were accumulated in SSP followed by gypsum whereas, minimum protein content were recorded in control. The interactive effect of genotypes $x$ sources (Table 5) of sulphur showed statistically significant difference for protein content accumulation. PG-1058 x SSP produced maximum protein content. Whereas, minimum protein assimilation was recorded in PG-1058 x control. These results are in accordance with findings of Jamal et al., (2006) who reported significant increase in protein content with application of sulphur @ $20 \mathrm{~kg}$ per ha. In the same way, these results are in accordance with findings of Tathe et al., (2008). They reported significant increase in protein content with application of sulphur @ $120 \mathrm{~kg} \mathrm{ha}^{-1}$.

Among groundnut genotypes (Table 4) Bari-2011 accumulated maximum palmitic acid content followed Golden and PG-1058 while minimum palmitic acid content was recorded in Bard-92. Sources of sulphur also depicted significant response for palmitic acid. SSP accumulated maximum palmitic acid content accumulation while minimum was recorded in control. Bari-2011 x gypsum (Table 5) produced maximum palmitic acid content whereas minimum was recorded in PG-1058 x control. Other interactive effects showed varied degree of difference. These results are in line with the findings of Jaggi (1994) who used different sources and levels of sulphur and found significant increase in amino acid content with the application of sulphur @ $60 \mathrm{~kg} \mathrm{ha}^{-1}$.

Among genotypes (Table 4) Bari-2011 accumulated maximum stearic acid content followed by PG-1058 while minimum stearic acid content was recorded in Bard-92. Among sources of sulphur SSP accumulated maximum stearic acid followed by SOP and gypsum while minimum stearic acid content was recorded in control. The interactive effect of genotypes $x$ sources of sulphur also showed statistically significant difference for stearic acid accumulation. Golden x SSP (Table 5) produced maximum stearic acid content while minimum stearic acid accumulation was recorded in PG-1058 x control. These results are in line with the findings of Jaggi (1994) who used different sources and levels of sulphur and found significant increase in amino acid content with the application of sulphur @ $60 \mathrm{~kg}$ through SSP.

Genotypes (Table 4) showed statistically nonsignificant differences for linolenic acid content. Among sulphur sources, maximum linolenic acid content accumulation was recorded in SSP followed by SOP and gypsum, whereas, minimum was recorded in control. The interactive effect of genotypes x sources of sulphur (Table 5) showed statistically significant difference for linolenic acid content. Golden $\mathrm{x}$ gypsum produced maximum linolenic acid content whereas, minimum linolenic acid assimilation was recorded in PG-1058 x control. These results are in line with the findings of Jaggi (1994) who used different sources and levels of sulphur and found 
significant increase in amino acid content with the application of sulphur@ $60 \mathrm{~kg} \mathrm{ha}^{-1}$.

Among genotypes (Table 4) maximum oleic acid was accumulated in PG-1058 which was statistically at par with Bari-2011 while minimum was recorded in Bard-92 followed by Golden. Sources of sulphur also depicted a significant response for oleic acid content. SOP accumulated maximum oleic acid content followed by gypsum. Whereas, minimum oleic acid content was recorded in control. PG-1058 x SSP (Table 5) produced maximum oleic acid content while minimum oleic acid was accumulated in Bard-92 x control. These results are in line with Jaggi (1994) who uses different sources and levels of sulphur and found significant increase in amino acid content with the application of sulphur @ $60 \mathrm{~kg}$ through SSP.

\section{Conclusion}

It is concluded from present study that sulphur sources had significant positive effects on yield and yield related parameters of groundnut genotypes. However, the oil content was unaffected. Among genotypes Bari-2011 produced maximum yield and oil content.

\section{References}

Abd El-Hady and B.A. 2007. Effect of zinc application on growth and nutrient uptake of barley plant irrigated with saline water. Journal of Applied Sciences and Resources 3(6): 431-436.

Ahmed A. and M.Z. Abdin. 2000. Interactive effect of Nitrogen and Sulfur on the oil and protein contents and on the fatty acid profiles of oil in the seeds of rapeseed (Brassica campestris L.) and musard (Brassica juncea L. Czern and Coss). Journal of Agronomy \& Crop Science 183: $1-6$

Awad, A., K. Chan, A. Downie. and C. Fink. 2000. Peanut as a source of beta-sitosterol, a sterolwith anticancer properties. Nutrition Cancer 36(2): 238-241

Chattopaddhyay, S. and G.K. Ghosh. 2012. Response of rapseseed (Brassica junceaL.) to various sources and levels of sulphur in red and lateritic soils of West Bengal, India. International Journal of plant, animal and environmental 2(4): 50-59.

Coates A. and P. Howe. 2007. Edible nuts and metabolic health. Current Opinions in Lipidology 18, 25-30.

Das, R.K.B. and Garnayak. 1995. Response of groundnut to calcium application in red alluvial soils of Orissa. Indian Journal of Environment and Ecology 13(1):59-62

Din, U.N., A. Mehmood, G.S. Khattak, I. Saeed, and M.F. Hassan. 2009. High yielding groundnut (Arachis hypogaea L.) variety "Golden". Pakistan Journal of Botany 41(5): 2217-2222
Dutta, R.R., N.C. Deka, and K. Neog. 2000. Effect of different levels of sulphur on groundnut in sandy loam soils of Assam. Geobios (Jodhpur)34(2-3)121-124

Dwivedi, A.K., and P.N. Bapat. 1998. Sulphur-Phosphorus interactions on the synthesis of nitrogenous fractions and oil in soyabean. Indian Journal of Soil Sciences 46: 254257.

EL-Kader, Abd and G. Mona. 2013. Effect of Sulfur Application and Foliar Spraying with Zinc and Boron on Yield, Yield Components, and Seed Quality of Peanut (Arachis hypogaea L.). Research Journal of Agriculture \& Biological Sciences 9(4): 127.

Etherton, Kris, E.P, T. Pearson, Y. Wan, R. Hargrove, K. Moriarty, V.Fishell and T. Etherton. 1999. Highmonounsaturated fatty acid diets lower both plasma cholesterol and triacylglycerol concentrations. American Journal of Clinical Nutrition 70: 1009-1015.

Gee, G.W. and J.W. Bauder. 1982. Hydrometer Method. P. 383-411. In A. Klute, (ed.), Methods of Soil Analysis. Part 1. American Society of Agronomy No. 9. Incorporation. Soil Science American Incorporation Madison, Wisconsin, USA.

Ghosh, P.K., K.M. Hati, K.G. Mandal, A.K. Misra, A.S. Chaudhary and K.K. Bandyopadhyay. 2000. Sulphur nutrition in oilseeds and oilseed-based cropping systems. Fertilizer News 45(8):27-40.

Hossain, M.A., M.S.A. Khan, S. Nasreen and M.N. Islam. 2006. Effect of seed size and phosphorus fertilizer on root length density, $\mathrm{P}$ uptake, matter production and yield of groundnut. Journal of Agriculture Research 44(2): 127-139.

Ishag, H.M. 1992. Effects of Foliar Micronutrient Fertilizers on the Yield of Irrigated Cotton on the Vertisols of the Sudan Gezira. Experimental Agriculture 28: 265-271.

Jaggi, R.C. 1994. Response of Raya (Brassica jucea L.) to sulphur through different sources in an acid alfisol. Indian Journal of Soil Sciences. 42: 281-284.

Jamal, A., I.S. Fazli, S. Ahmad and M.Z. Abdin. 2006. Interactive effect of nitrogen and sulphur on yield and quality of groundnut (Arachis hypogaea L.). Korean Journal of Crop Sciences 15(6): 519-522.

Jamal, A., Y.S. Moon and M.Z. Abdin. 2010. Sulphur a general overview interaction with nitrogen. Australian Journal of Crop Sciences 4(7): 523-529

Jiang, R., J. Manson, M. Stampfer, S. Liu, W. Willett and F. Hu. 2000. Nut and peanut butter consumption and risk of type 2 diabetes in women. Journal of American Medical Association 20, 2554-2560.

Kalaiyarasan, C., V. Vaiyapuriand and M.V.R. Skharan. 2002. Effect of sulphur sources and yield of groundnut in red lateritic soil. Annals of Agriculture Research 23(4): 618-621. 
Kumaran, S. 2001. Responce of groundnut to organic manure, fertilizer levels, split application of phosphorus and gypsum application under irrigated condition. Research on Crops 2(2): 156-158.

Messina, M. 1999. Legumes and soybeans: overview of their nutritional profiles and health effects. American Journal of Clinical Nutrition 70, 439-450.

Mishra, U.K., S.K. Sahu, R. Das and G.N. Mitra. 1999. Effect of sulphur and lime on yield and oil content of kharif groundnut grown in sandy loam soil. Journal of Indian Society of Soil Sciences 38(4): 772-774.

Montgomery, D.C. (2001). Design and Analysis of Experiments, John Wiley \& Sons. New York, 64-65.

Nabi, G., M. Salim and Rahmatullah. 1999. Yield responses of rainfed groundnut to sulphur and phosphorus application. Pakistan Journal of Biological Sciences 2(3): 911-913.

Nazir, S.E. Bashir and R. Bentil. 2011. Crop Production, Oilseed crops, Groundnut $5^{\text {th }}$ ed. National Book Foundation Islamabad. Pakistan. 14:351-358.

Nelson, D.W and L.E. Sommers. 1982. Carbon, organic carbon and organic matter. In: Page, A.L., R.H. Miller and D.R. Keeney, (eds.), Methods of Soil Analysis Part 2: Chemical and Microbiological Properties. American Society of Agronomy 9: 539-580.

Onyeike, E.N. and J.U. Oguike. 2003. Influence of heat processing methods on the nutrient composition and lipid characterization of groundnut seed pastes. Nigerian society of Experimental Biology 15(1): 34-43.

Poonia, K.L. 2000. Effect of planting geometry, nitrogen and sulfur on growth and yield of sunflower (Helianthus annuus L.). Journal of Ecology and Physiology 3: 59-71.

Prasad, B. 2003. Direct and residual effects of different sulphur fertilizers ongroundnut and wheat cropping system on typic haplaquent soils. Journal of Plant Nutrition 26(5): 997-1008.

Ramdevputra, M.V., K.N. Akbari, G.S. Sutaria, V.D. Vora and D.R. Padmani. 2010. Effect of sulphur application on yield of groundnut and soil fertility under rainfed conditions. International Journal of Legume Research 33(2): 143-145.

Rhoades, D.L. 1996. Salinity: Electrical Conductivity and total dissolved salt. p. 417-436. In Spark (ed.) Method of Soil Analysis Part 3 - Chemical Method. American Society of Agronomy No. 15 Incorporation, Soil Science Society of America Incorporation, Madison Wisconsin, USA.
Rhoades, J.D. and M. Polemio. 1977. Determining cation exchange: A new procedure for calcareous and gypsiferous soils. Soil Science Society of America Journal 41: 524-300.

Saito, K. 2004. Sulphur assimilatory metabolism. Plant Physiology 136: 2443-2450.

Sarkar, S.K., M.A.H. Chowdhury and H.M. Zakir, 2002. Sulphur and boron fertilization on yield quality and nutrient uptake by Bangladesh soybean-4. Journal of Biological Sciences 2: 729-733.

Shokunbi, O.S., E.T. Fayomi, O.S. Sonuga and G.O. Tayo. 2012. Nutrient composition of five varieties of commonly consumed Nigerian groundnut (Arachis hypogea L.). Biochemistry Department, Babcock University, Ilisan Remo, Ogun State, Nigeria. 63(1): 1418.

Singh, Y.P. and J.S. Mann. 2007. Interaction effect of sulphur and zinc in groundnut (Arachis hypogaea) and their availability in Tonk district of Rajasthan. Indian Journal of Agronomy 52(1), 70-73.

Sisodiya, R.R., N.B. Babaria, T.N. Parmar and K.B. Parmar. 2017. Effect of sources and levels of sulphur on yield and micronutrient ( $\mathrm{Fe}, \mathrm{Mn}, \mathrm{Zn}$ and $\mathrm{Cu}$ ) absorption by groundnut (Arachis hypogaea L.). International Journal of Agriculture Sciences 9(32): 4465.

Smith, A.F. 2002. Peanuts: The Illustrious history of the goober pea. Chicago: University of Illinois Press.

Soltanpour, P.N and S. Workman. 1981. Soil testing methods used at ColoradoState University Soil Testing Laboratory for the evaluation of fertility, salinity, sodicity and trace element toxicity. Technical Bull.

Subhendu, M., R.C. Samui, and M. Anirban. 2005. Growth yield attributes of groundnut cultivars as influenced by gypsum application. An International Journal of Legume Research 28(2): 119-121.

Tabatabaei, M.A., 1986. Sulfur in Agriculture. American Society of Agronomy. Madison, WI., USA.

Tathe, A.S., G.D. Patil and J. Khilari. 2008. Effects of sulphur and zinc on groundnut in vertisols. An Asian Journal of Soil Sciences 3(1): 178-180.

Thomas, G.W. and A. Hipp. 1996. Soil pH and soil acidity. p. 475-490. In Spark (ed.) Method of Soil Analysis Part 3 - Chemical Method. American Society of Agronomy No. 15 Incorporation, Soil Science Society of America Incorporation, Madison Wisconsin, USA. 